\title{
BIOSORPTION OF Hg (II) FROM AQUEOUS SOLUTIONS USING BUTEA MONOSPERMA
}

\author{
Mallappa A. Devani ${ }^{1}$, Basudeb Munshi ${ }^{2}$, John U. Kennedy Oubagaranadin ${ }^{3}$, Bipin Bihari Lal ${ }^{4}$ \\ ${ }^{1,2}$ Department of Chemical Engineering, National Institute of Technology, Rourkela 769008, Orissa, INDIA \\ ${ }^{3}$ Department of Ceramic and Cement Technology, PDA College of Engineering, Gulbarga, Karnataka, INDIA: \\ ${ }^{4}$ Department of Civil Engineering, Bheemanna Khandre Institute of Technology, Bhalki, Karnataka, INDIA \\ mdevani003@gmail.com and basudebmyahoo.com,ju_kennedy@yahoo.co.in, bipinji@yahoo.com
}

\begin{abstract}
The objective of this study is to investigate the feasibility of using Butea monosperma leaves powder (BMLP) for the removal of mercury from aqueous solution at the normal $\mathrm{pH}$ of the solution and at room temperature $\left(30^{\circ} \mathrm{C}\right)$. Results show that BMLP has a good biosorption capacity for mercury. The biosorption isotherms were analyzed using Freundlich, Langmuir and Temkin models. The Freundlich model yielded the best fit for the experimental biosorption equilibrium data. The maximum monolayer biosorption capacity as determined from the Langmuir model is $62.235 \mathrm{mg} / \mathrm{g}$ of biosorbent for initial concentration of 150 ppm mercury in the solution. The biosorption energy, $\triangle Q$ indicates that the biosorption reaction was endothermic. The kinetic data fitted the Ho's pseudosecond-order model with correlation coefficient 0.9985 and 0.9620 for initial concentration of 100 ppm and 150 ppm mercury in the solution. The studies suggest that the sorbent can be used for the removal of mercury from aqueous solutions.
\end{abstract}

Keywords: Biosorption, Mercury, Isotherms, Kinetics

\section{INTRODUCTION}

Today worldwide heavy metal pollution is a dangerous threat to human and animals both in developed and developing countries. The most toxic metals given in the report by the United States Environmental Protection Agency (USEPA, 1978) are antimony, arsenic, beryllium, cadmium, chromium, copper, lead, mercury, nickel, selenium, silver, thallium and zinc. These metals are neither biodegradable nor destroyable; therefore removal of them is extremely necessary from water/wastewater [1].

Biosorption is most emerging technique studied worldwide since last 10 years, due to its potential in treatment of wastewater [2-3]. Biosorbents of agricultural origin have polar functional groups of protein lignin, carbohydrates and phenolic compounds that have carboxyl, hydroxyl, sulfate, and amino groups, polymeric groups like cellulose, hemi-cellulose, pectin, lignin and proteins as active centers for metal uptake [4]. Many researchers have made significant contributions in this area, utilizing a number of agro-based materials such as rice husk, coconut shell, walnut hazelnut and almond shell, cotton seed hull, bagasse pith, papaya wood, sun flower stem, etc. [5-7].

The objective of the present study was to explore the potential of Butea monosperma leaves powder (BMLP) for the removal of $\mathrm{Hg}(\mathrm{II})$ from the aqueous solutions. The Butea monosperma leaves are in enormous supply, inexpensive and easily found around in forest.

\section{EXPERIMENTAL}

\subsection{Biosorption Equilibrium Experiments}

$50 \mathrm{ml}$ solutions of $100 \mathrm{ppm} \mathrm{Hg}(\mathrm{II})$ concentration were dosed with $0.05 \mathrm{~g}, 0.1 \mathrm{~g}, 0.15 \mathrm{~g}, 0.2 \mathrm{~g}, 0.25 \mathrm{~g}, 0.3 \mathrm{~g}, 0.35 \mathrm{~g}, 0.4 \mathrm{~g}$ and $0.45 \mathrm{~g}$ of average size $0.5125 \mathrm{~mm}$ biosorbent and was shaken in an orbital shaker for about $4 \mathrm{hrs}$ for equilibration. The solutions were then filtered and the residual $\mathrm{Hg}(\mathrm{II})$ concentrations were determined spectrophotometrically as reported [8]. A similar set of experiments was performed with an initial $\mathrm{Hg}(\mathrm{II})$ concentration of $150 \mathrm{ppm}$.

\subsection{Kinetic Experiments}

Batch kinetic studies were carried out in a $250 \mathrm{ml}$ glass beaker. $0.1 \mathrm{~g}$ of average size $0.5125 \mathrm{~mm}$ biomass was added to $25 \mathrm{ml}$ metal solution of $100 \mathrm{ppm} \mathrm{Hg}$ (II) concentration and was shaken in an orbital shaker. Samples were withdrawn at different time intervals of $30 \mathrm{Sec}, 1 \mathrm{~min}, 3 \mathrm{~min}, 6 \mathrm{~min}, 10 \mathrm{~min}$, $25 \mathrm{~min}, 45 \mathrm{~min}, 60 \mathrm{~min}, 75 \mathrm{~min}$, and $90 \mathrm{~min}$. Samples were immediately vacuum filtered by using Gooch sintered ware grade $\mathrm{G} 4$ and the residual concentration of $\mathrm{Hg}$ (II) were determined spectophotometrically. A similar set of experiments was performed with an initial $\mathrm{Hg}(\mathrm{II})$ concentration of $150 \mathrm{ppm}$. 


\section{RESULTS AND DISCUSSION}

\subsection{Equilibrium Studies}

In this study three isotherm models were to used to test the equilibrium biosorption of $\mathrm{Hg}$ (II) onto $B M L P$.

\section{Freundlich Isotherm}

This model normally gives a better fit mainly for biosorption from liquids and can be expressed as [9]:

$$
q_{e}=K_{F} C_{e}^{1 / n}
$$

Where $q_{e}(\mathrm{mg} / \mathrm{gm})$ is the amount of adsorbate biosorbed at equilibrium and $\mathrm{C}_{\mathrm{e}}(\mathrm{mg} / \mathrm{L})$ is the equilibrium concentration of adsorbate in solution. In this model, the mechanism and the rate of adsorption are functions of the constants, $1 / n$ and $K_{F}$ $(\mathrm{L} / \mathrm{mg})$ respectively. The value of the plots for the biosorption of $\mathrm{Hg}$ (II) on BMLP given in the table 1. The plots give good fit $\left(\mathrm{R}^{2}=0.9945\right.$ for $100 \mathrm{ppm}$ and 0.9921 for $\left.150 \mathrm{ppm}\right)$. For a good biosorbent, $0.2<1 / n<0.8(0.3368$ for $100 \mathrm{ppm}$ and 0.6036 for $150 \mathrm{ppm}$ ) A smaller value of $1 / n$ indicates better biosorption and formation of relatively strong bond between the adsorbate and biosorbent.

\section{Langmuir Isotherm}

This model is valid for monolayer biosorption onto surface having finite number of similar sorption sites which is presented by the following equation [10]:

$$
q_{e}=\frac{q_{m} K_{L} C_{e}}{1+K_{L} C_{e}}
$$

In this model, $q_{\mathrm{m}}(\mathrm{mg} / \mathrm{g})$ is the metal biosorbed corresponding to complete monolayer coverage, i.e., the maximum biosorption capacity, $\mathrm{C}_{\mathrm{e}}$ is equilibrium concentration of the solution $(\mathrm{mg} / \mathrm{L})$, and $K_{\mathrm{L}}(\mathrm{L} / \mathrm{mg})$ is the Langmuir constant. From the values of $q_{\mathrm{m}}$, as shown in the Table No. 1 , it is observed that the maximum biosorption capacity of $B M L P$ is $26.719 \mathrm{mg} / \mathrm{g}$ and $62.235 \mathrm{mg} / \mathrm{g}$ for initial concentration of mercury $100 \mathrm{ppm}$ and $150 \mathrm{ppm}$ respectively.

For Langmuir type process, to determine if the biosorption is favorable or not, a dimensionless separation factor is defined as [11]:

$$
R_{L}=\frac{1}{1+K_{L} C_{0}}
$$

If $R_{L}>1$, the isotherm is unfavorable

$R_{L}=1$, the isotherm is linear
$0<R_{L}<1$, the isotherm is favorable

$R_{L}=0$, the isotherm is reversible.

The value of $R_{L}$ for Butea monosperma (0.01104 for 100 ppm mercury and 0.08025 for $150 \mathrm{ppm}$ mercury) falls between 0 and 1, indicating that the isotherms are favorable. Fig.1 shows a plot of residual equilibrium concentration $C_{e}$ (ppm) against adsorbate loading $q_{e}(\mathrm{mg} / \mathrm{g})$. The curves are convex upward and so they are favorable because a relatively high adsorbate loading can be obtained at low concentration in the solution.

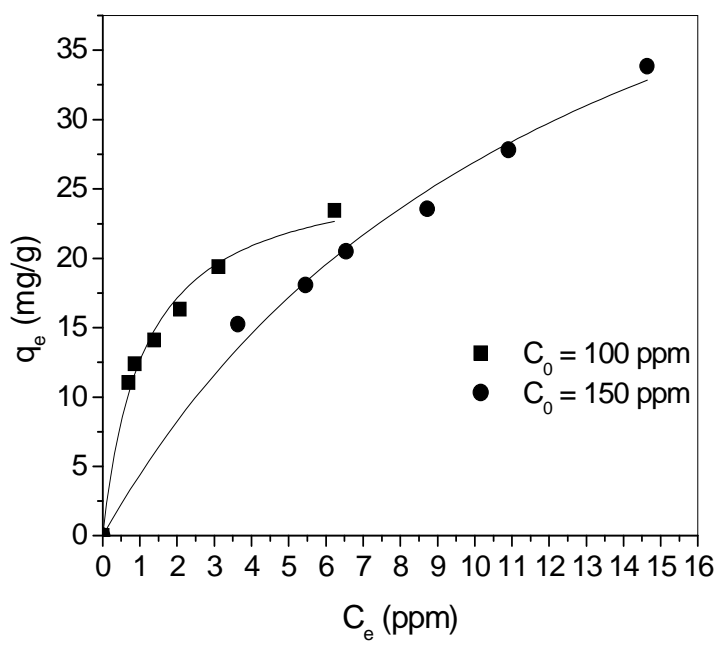

Fig1. Equilibrium data for the biosorption of $\mathrm{Hg}$ (II) on Butea monosperma

\section{Temkin Isotherm}

The derivation of the Temkin isotherm assumes that the fall in the heat of biosorption is linear rather than logarithmic, as implied in the Freundlich equation.

The Temkin isotherm is expressed as [12]:

$$
q_{e}=\frac{R T}{\Delta Q} \ln \left(K_{T} C_{e}\right)
$$

The parameters of the Temkin model, which takes into account the biosorbing species-biosorbent interactions, gave a satisfactory fit to the experimental data. The biosorption energy, $\Delta Q(448 \mathrm{~kJ} / \mathrm{kmol}$ for $100 \mathrm{ppm}$ and $189 \mathrm{~kJ} / \mathrm{kmol}$ for $150 \mathrm{ppm}$ mercury in the solution), indicates that the biosorption reaction was endothermic. $K_{T}$ is the equilibrium binding constant $(\mathrm{L} / \mathrm{mg})$ corresponding to the maximum binding energy. From the values of $K_{\mathrm{T}}(9.7496$ and 0.7611 for an initial concentration of $100 \mathrm{ppm}$ and $150 \mathrm{ppm}$ mercury) it is observed that the binding energy is better for $B M L P$. 
Table1. Isotherm modeling for the biosorption of $\mathrm{Hg}$ (II) onto Butea monosperma

\begin{tabular}{|l|l|c|c|c|l|}
\hline Model & Equation & $\mathrm{R}^{2}$ & $\chi^{2}$ & $\begin{array}{c}\mathrm{C}_{0} \\
(\mathrm{ppm})\end{array}$ & Parameter values \\
\hline 1. Freundlich & $q_{e}=K_{F} C_{e}^{1 / n}$ & 0.9945 & 0.1486 & 100 & $1 / n=0.3368 ; K_{F}=12.80$ \\
\cline { 2 - 6 } & \multirow{2}{*}{$q_{e}=\frac{q_{m} K_{L} C_{e}}{1+K_{L} C_{e}}$} & 0.9921 & 0.4574 & 150 & $1 / n=0.6036 ; K_{F}=6.599$ \\
\cline { 2 - 6 } & 0.9912 & 1.2169 & 150 & $q_{m}=62.235 ; K_{L}=0.0764$ \\
\hline \multirow{2}{*}{ 3. Temkin } & $q_{e}=\frac{R T}{\Delta Q} \ln \left(K_{T} C_{e}\right)$ & 0.9903 & 0.2636 & 100 & $\begin{array}{l}\Delta Q=448 \mathrm{~kJ} / \mathrm{kmol} ; \\
\mathrm{K}_{\mathrm{T}}=9.7496\end{array}$ \\
\cline { 2 - 6 } & 0.9553 & 2.5904 & 150 & $\begin{array}{l}\Delta Q=189 \mathrm{~kJ} / \mathrm{kmol} ; \\
\mathrm{K}_{\mathrm{T}}=0.7611\end{array}$ \\
\hline
\end{tabular}

\subsection{Kinetic Studies}

Information about the biosorption mechanism is provided by kinetic study of biosorption. In this study, two different kinetic models were applied in order to establish which of them shows the best fit with experimentally obtained data.

\section{Pseudo-first-order (Lagergren) model}

This model is frequently used in kinetic studies and is the earliest known one explaining the rate of biosorption based on the biosorption capacity [13]. It is given by:

$$
\frac{d q_{t}}{d t}=k_{1}\left(q_{e}-q_{t}\right)
$$

Where, $\mathrm{q}_{\mathrm{t}}$ is uptake at any time ' $\mathrm{t}$ ', $\mathrm{q}_{\mathrm{e}}$ is equilibrium uptake and $\mathrm{k}_{1}$ is first order rate constant. The experimental data gives good fit for $B M L P\left(\mathrm{R}^{2}=0.9963\right.$ and 0.9247 for $100 \mathrm{ppm}$ and $150 \mathrm{ppm}$ mercury concentration). The values of the first-order rate constant $\left(k_{1}\right)$ are 4.898 and $2.457 \mathrm{~min}^{-1}$ for $100 \mathrm{ppm}$ and $150 \mathrm{ppm}$ mercury.

\section{Pseudo second-order (Ho) model}

The kinetic equation is written in the form [14]:

$$
q_{t}=\frac{q_{e}{ }^{2} k_{2} t}{1+q_{e} k_{2} t}
$$

The data gives perfect fit for this model for $B M L P\left(\mathrm{R}^{2}=\right.$ 0.9985 and 0.9625 for initial concentration of $100 \mathrm{ppm}$ and 150 ppm mercury) as shown in Fig.2 compared to Lagergren's first-order rate equation. The values of the second-order rate constants found from of the graphs for BMLP $\left(k_{2}=0.8261\right.$ $\mathrm{gm} /(\mathrm{mg}-\mathrm{min})$ and $0.1490 \mathrm{gm} /(\mathrm{mg}-\mathrm{min})$ for $100 \mathrm{ppm}$ and 150 ppm mercury) indicate that $\mathrm{Hg}(\mathrm{II})$ removal rate is very fast.

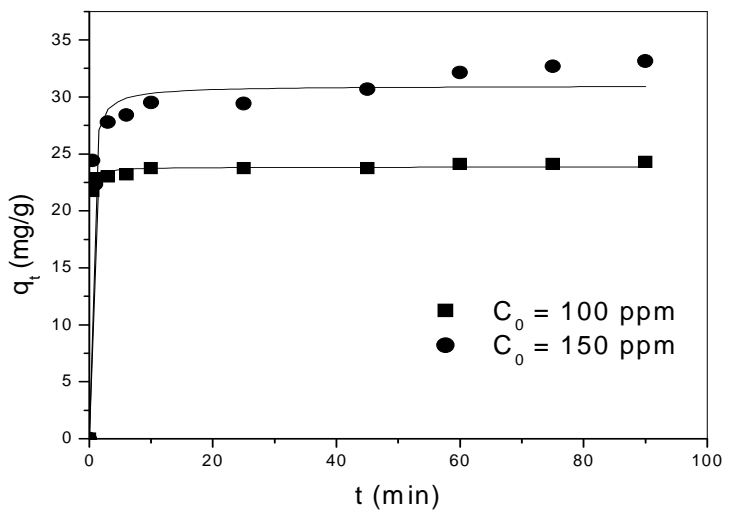

Fig2. Kinetic data for the biosorption of $\mathrm{Hg}(\mathrm{II})$ on Butea monosperma

Table2. Kinetic modeling of biosorption of $\mathrm{Hg}$ (II) by Butea monosperma

\begin{tabular}{|c|c|c|c|c|c|}
\hline Model & Equation & $\mathrm{R}^{2}$ & $\chi^{2}$ & $\mathrm{C}_{0}(\mathrm{ppm})$ & Parameter values \\
\hline $\begin{array}{l}\text { 1. Pseudo- } \\
\text { first-order } \\
\text { (Lagergren) }\end{array}$ & $q_{t}=q_{e}\left(1-e^{-k_{1} t}\right)$ & 0.9963 & 0.2087 & 100 & $q_{e}=23.66 ; k_{1}=4.898$ \\
\cline { 3 - 6 } & 0.9247 & 7.3495 & 150 & $q_{e}=30.15 ; k_{l}=2.457$ \\
\hline $\begin{array}{l}\text { 2. Pseudo- } \\
\text { second- } \\
\text { order (Ho) }\end{array}$ & $q_{t}=\frac{q_{e}{ }^{2} k_{2} t}{1+q_{e} k_{2} t}$ & 0.9985 & 0.0870 & 100 & $q_{e}=23.86 ; k_{2}=0.8261$ \\
\cline { 5 - 7 } & & 0.9620 & 3.7061 & 150 & $q_{e}=30.97 ; k_{2}=0.1490$ \\
\hline
\end{tabular}




\section{CONCLUSIONS}

In the present study, the potential of using $B M L P$ was assessed for the removal of $\mathrm{Hg}$ (II) from aqueous solutions. The Freundlich model fitted the experimental data well. The BMLP exhibits a maximum biosorption capacity of $62.235 \mathrm{mg} / \mathrm{g}$ for initial metal concentration of $150 \mathrm{ppm}$. Biosorption followed pseudo-second order rate model as indicated by very high value of coefficient of correlation 0.9912. Since the raw material (Butea monosperma) is freely available in large quantities as a waste, it can be used economically for $\mathrm{Hg}$ (II) removal from polluting waters.

\section{REFERENCES}

[1] T. Akar and S. Tunali, "Biosorption Performance of Botrytis Cinerea Fungal by Products for Removal of $\mathrm{Cd}(\mathrm{II})$ and $\mathrm{Cu}(\mathrm{II})$ Ions from Aqueous Solutions", Minerals Engineering, Vol.18, 2005, pp.1099-1109.

[2] K. H. Chong and B. Volesky, "Description of Two Metal Biosorption Equilibria by Langmuir type Models", Biotechnology and Bioengineering, Vol. 47, 1995, pp. 451-60.

[3] [3] A. D. Crowall, "Surface and Solid Gas Interface", New York, Marcel Dekker, 1966.

[4] F. Pagnanelli, S. Mainelli, F. Veglio and L. Toro, "Heavy Metal Removal by Olive Pomace: Biosorbent Characterization and Equilibrium Modeling," Chemical Engineering Science, Vol. 58, pp. 4709-4717, 2003.

[5] D. Sud, G. Mahajan and M. P. Kaur, "Agricultural Waste Material as Potential Adsorbent for Sequestering Heavy Metal Ions from Aqueous Solutions - A Review," Bioresource Technolology, Vol. 99, pp. 60176027, 2008.

[6] T. Altun and E. Pehlivan, "Removal of Copper(II) Ions from Aqueous Solutions by Walnut, Hazelnut and Almond shells," Clean-Soil Air Water, Vol. 35, pp. 601-606, 2007.

[7] N. A. Khan, S. Ibrahim, P. Subramaniam, "Elimination of Heavy Metals from Wastewater using Agricultural Wastes as Adsorbents," Malays Journal of Science, Vol. 23, pp. 43-51, 2004.

[8] T. V. Ramakrishna, G. Aravamudan and M. Vijayakum ar, "Spectrophotometric Determination of Mercury (II) as the Ternary Complex with 6G and Iodide," Analytica Chimica Acta, Vol. 84, pp. 369-375, 1976

[9] H. M. F. Freundlich, "Over the Adsorption in Solution," Journal of Physical Chemistry, Vol. 57, pp. 385-471, 1906

[10] Langmuir, "The Adsorption of Gases on Plane Surfaces of Glass, Mica and Platinum," Journal of American Chemical Society, Vol. 40, pp. 1361-1368, 1918.

[11] T. W. Weber and R. K. Chakkravorti, "Pore and Solid Diffusion Models for Fixed Bed Adsorbents", American Institute of Chemical Eng. Journal, Vol. 20, pp. 228-238, 1974
[12] F. Xian-cai and C. Qui-hui, "Physical Chemistry", Higher Education Press, China, pp. 303-321, 1988

[13] John U. Kennedy Oubagaranadin and Z.V.P. Murthy, "Modeling of Adsorption of Chromium(VI) on Activated Carbons Derived from Corn (Zea mays) Cob," Chemical Product and Process Modeling, Vol. 4, Issue 1, 2009.

[14] Y. Ho, and A. E. Ofemaja, Pseudo - Second order Model for Lead Ion Sorption from Aqueous Solutions onto Palm Kernel fiber," Journal of Hazardous Materials, Vol. 129, pp. 137-142, 2006. 